\title{
PLANNING PARTICIPATORY COMMUNICATION INTERVENTIONS FOR SUSTAINING WOMEN'S COLLECTIVES (SHGs): FIELD EVIDENCE FROM INDIA
}

\author{
MILI SHARMA ${ }^{1} \&$ DR. SANJAY MOHAN JOHRI ${ }^{2}$ \\ ${ }^{1}$ Scholar, Amity School of Communication, Amity University, Uttar Pradesh (AUUP), Lucknow Campus, Lucknow, \\ Uttar Pradesh, India \\ $2 *$ Director, Professor-Director, Amity School of Communication, Amity University, Uttar Pradesh (AUUP),
} Lucknow Campus, Lucknow, Uttar Pradesh, India

\begin{abstract}
The purpose of the study is to propose an outline to develop a participatory communication intervention for women SHGs. A mixed method approach has been adopted through intensive interviews of communication facilitators involved in SHGs from Lucknow (Uttar Pradesh, India) to conclude that NGOs followed the guidelines given by World Bank to develop efficient communication interventions. The quantitative tool involving SHG members proves that interventions have also led to social, political, economic, psychological, cultural and legal empowerment of women. It has also changed lives of women by way of resource building, coalition building and partnership. The research highlights there have been changes in day to day activities of women as well as their behaviour after they became a part of SHGs. Development agencies, NGOs and governments can take cues from the research to develop sustainable mechanisms to empower women.

KEYWORDS: Participatory Communication Intervention, Behaviour Change, Women Empowerment, Resource Building, Coalition Building \& Communication Facilitator
\end{abstract}

Received: Jun 11, 2020; Accepted: Jul 01, 2020; Published: Jul 13, 2020; Paper Id.: IJMPERDJUN2020310

\section{INTRODUCTION}

\section{Defining SHGs and Intervention}

Created at the grass root level and based on the principle of joint responsibility and mutual help SHGs are small informal associations of the poor. The purpose is to save small but regular amounts of money as common fund for crisis situation and take up income generating activity as a group for social and economic well-being.

On the other hand, an intervention is any intentional interference which can transform a process, condition or situation (Soydan, 2010). This may be change in a program, a policy or practice that is popular. The important fact about interventions is they focus on people's behaviour and how changes in the environment can support those behaviours. It describes a thoughtful association in a process or system with the intention to influence events and/or consequences (Belcher \& Palenberg, 2018).

\section{Participatory Communication Intervention}

As a part of the study, we are concerned with participatory communication which began to hold attention during the late 1980s/early 1990s with horizontal flow of communication as the focal point. This was in contrast to the traditional top-down model that dealt with a sender, a message and a receiver. The importance is more on a user and bottom-up oriented approach to involve people in decision making process (Servaes, 1996). Another characteristic is that it should be considered as a process rather than as a static model. This means participatory communication should be 
an inherent element throughout all the phases of any development intervention. Finally there cannot be a pre-set; one shoe fits all formula for universal messages, channels or models to be followed. The quest should be for the most appropriate way according to situation and culture (Melkote, 1991; Servaes, 1991). Nobuya Inagaki states that interpersonal communication is an extensively accepted approach in communication interventions including participatory approaches. It is meant to not only pass on information produced by experts and non-local actors but also to generate new practices and knowledge. Group communication is a kind of interpersonal communication, used in contexts where people engage in issues belonging to community importance. The concept of SHG uses interpersonal communication.

\section{OBJECTIVES OF STUDY}

- To understand how to develop participatory communication interventions in the context of SHGs.

- To discuss how participatory communication intervention outcomes have led to women empowerment.

\section{METHODOLOGY}

The researchers have chosen the advocacy or participatory worldview for their research study. Kemmis and Wilkinson (1998) observe that participatory studies begin with a fundamental stance about the problems facing the society, such as need for empowerment. They have emancipation as a basic streak as it helps people break the fetters of irrational and unjust structures.

\section{Study Settings \& Context}

The study is conducted in Lucknow district of Uttar Pradesh, India. Lucknow district has eight blocks, namely, BakshikaTaalab, Chinhat, Gosaiganj, Kakori, Mal, Malihabad, Mohanlalganj and Sarojini Nagar. From each block, not less than two SHGs were taken which were selected randomly. Interview guides for collecting data from NGO staff working as communication facilitators (from each block) were prepared. Data was collected through personal and telephonic interviews and by mailing of Interview Schedules to them. A total of 13 interviews with facilitators of SHGs were done.

For discussing how participatory communication intervention is leading to women empowerment, from each block, not less than two SHGs were taken which were selected randomly. In each group, ten members were selected on the basis of consecutive sampling. From total eight blocks, a sample of 240 women participating in the SHGs was selected. So the total sample of the study consisted of 240 women SHG members. The data was analysed using SPSS 20 and collected by the researcher through administering a schedule. Descriptive statistics including frequency, percentages, mean ranks, Kruskal Wallis test were applied and obtained.

\section{Study Design \& Participants}

The researchers used semi-structured interview format which was followed by interview protocol that is asking questions and recording answers. Respondents were thoroughly briefed about the purpose of inquiry and data analysis was done using a linear, hierarchical approach building from the bottom to top. Using intensive interviews as main data collection tool, the researchers transcribed interviews verbatim (Poland, 2005) and translated them from local language (Hindi) into English. This is because many contextual nuances of the language get lost in translation. Keeping in mind the need for triangulation, to assure validity of the process (Tellis, 1997) the researchers focused on investigator triangulation (Denzin, 1984). According to this method, the two authors scrutinized each other's interpretation of the interview to establish truth. Thereafter, trustworthiness was assured with the help of engagement, continuous observations, peer debriefing, thick description and purposive sampling (Erlandson et al, 1993).The researchers carried out a thematic analysis by identifying 
general themes/patterns. A number of themes emerged through iterative reading of the transcripts (Rice \&Ezzy, 1999). The analysis continued until theoretical saturation.

\section{INTERPRETATION \& DISCUSSION}

In order to study the communication intervention in SHGs, the researchers took the help of World Bank (2009) data outlining different steps to design and implement a communication intervention. Each step is elaborated by highlighting the information provided by communication facilitators in intensive interviews.

- To become acquainted with the situation and stakeholders. Decide what needs to happen and who the intervention should help. Identify targets of change and agents of change.

- To build and secure trust while engaging stakeholders in exploring and assessing the situation, that is, gather information about the level of problem. In case of SHGs, decide how the groups are to be formed. (Step 1 \& 2 will cover the preliminary survey \& the communication strategies to be used by facilitators for forming SHGs).

The interviewees opined that interaction with elders/ 'Pradhan' (headman) of the village along with public gatherings is used as a communication strategy for making SHGs. In colloquial language, facilitators try to subside fears of women that if they don't join SHG their 'Aadhar' card (identification card) will get cancelled or government pension will be stopped. Interpersonal communication along with identifying opinion leader to reach the community and also use of case studies and illustrations is focussed upon. Interaction with influential/known people like ASHA (Accredited Social Health Activist), 'Pradhan' is used as a communication strategy for making SHGs. The facilitators try to establish rapport by initial interaction and listening to what women have to say. Explaining the five sutras (principles) of SHGs, facilitators explain that if they save Re 1 everyday, they will have saved Rs.30 by the end of the month. There are oral presentations, case studies, brainstorming, games, cards, question-answer sessions to show how lower interest rates on loans can transform lives. They use tools like pictures, games and role play that are tweaked to incorporate cultural context.

The most common communication strategy used on the part of facilitators is face to face interaction. For example, it is important to drive home the point that offering collateral free loans is one of the objectives of SHG. Then keeping the cultural context of area in mind, role play, games and proverbs are used. For example, the marble game is a common strategy which infers that the rich have more access and control over resources. SHGs work in this direction for the marginalised.

- $\quad$ To identify, analyse and rank challenges, problems and opportunities.

- To analyse causes of major barriers, taking into consideration different perspectives. (Step 3 \& 4 will cover the challenges faced by facilitators while making SHGs).

For this step, the criteria developed by NABARD (National Bank for Agriculture and Rural Development, nodal agency for SHGs in India) to understand the type of families to visit for the process of forming SHGs was used. Facilitators ask these questions about each family.

- Is the family having only one earning member?

- Is the drinking water being brought from faraway place?

- Are the women forced to go far in the open for defecation? 
- Does the family have old illiterate people?

- Does the family have permanently ill members?

- Does the family have children who do not go to school?

- Is there a drunkard/drug addict in the family?

- Is the house made of 'kucha'(temporary) material?

- Does the family regularly borrow money from the money lenders?

- Do they eat less than two meals a day?

- Does the family belong to scheduled castes/tribes?

If 'yes' is the answer for three or four of these questions, one can consider the family as poor.

Communication facilitators have to clear air regarding distrust about the SHG concept. Cheating and duping women on the pretext of SHG is widespread. They also have to deal with false information about benefits and promise of loan from SHG. Facilitators have to deal with casual and herd mentality of women regarding SHG. Sometimes the non-cooperative attitude of banks for one document or other is problematic. Then misuse of funds by office bearers is another problem. Facilitators find it difficult to win trust of women. It is a task to make them understand that taking loan from SHG is cheaper because rate of interest will be less.

Challenges on the part of SHG members include blame game on part of bank officials who conveniently blame NGO staff for each and everything. Then there are instances of harassment on the level of RRBs. For example, Rs. 10k loan is entitled to Rs. 700 stamp duty. Facilitators have to deal with women who are willing to join SHG but do not want to put in effort like attending meetings. Also, some of them want the money they contribute to be returned back. Sometimes women are competitive, they have ill-feelings for others like why person in a problem is given preference for a loan when others are facing problems too! At times it is difficult to explain the concept of SHG and finding the appropriate opinion leader who can clear doubts. Sometimes the group is broken because some members may decide to move out. Facilitators find that at times strong members tend to dominate the SHG.

During income generating activity, sourcing of raw materials and storing them is problematic. First and foremost, it is difficult to find opinion leaders. There is no promise of bank loan or free sops which is contrary to expectations. Facilitators face problems like lack of understanding among women and not expressing their views and feelings. Also, it is difficult to organize women especially those who are expecting quick results from SHG, without putting in efforts. Facilitators have to deal with ego clashes, lack of field visits and lack of training programmes to upgrade income generating activities. Also, there is infighting among group members at times. Then there are problems in day to day functioning of SHG like limited cash flow in group, no-loan repayment by members and lack of information about government schemes. The facilitators face numerous challenges like wilful default by members, unwillingness to respect group members. Then there is at times erratic demand for product, frauds by market agents in accounts and difficulty in managing large amount of funds in absence of strong leadership. Lack of coordination and leadership skills is a major deterrent. Additionally, there is pressure from lending agencies and lack of strong control mechanism and governance system on the part of President, Secretary and Treasurer of SHG. 
Define best options and viable solutions to problems while turning them into SMART objectives.

When problems are identified in the SHGs, brainstorming and group discussions are done to find solutions. For example:

- $\quad$-There is an effort to reach common agreement on when to meet.

- $\quad$ penalties are agreed upon for non-attendance in meetings.

- agreement on amount of saving.

- $\quad$ giving small loans to each other.

- $\quad$ taking loans from banks, repayment habits.

- training of members is an important need for proper functioning of SHGs

Outline and position relevant audiences or stake holder groups. Highlight benchmarks/indicators regarding grading of SHGs.

Table 1: Checklist To Assess Performance of SHG

\begin{tabular}{|c|c|c|c|c|}
\hline $\begin{array}{r}\text { Sl } \\
\text { No. }\end{array}$ & $\begin{array}{c}\text { Factors to be } \\
\text { Checked }\end{array}$ & Very Good & Good & \\
\hline 1 & Group Size & $15-20$ & $10-15$ & Less than 10 \\
\hline 2 & Types of members & $\begin{array}{l}\text { Only very poor } \\
\text { members }\end{array}$ & 2 or 3 not very poor members & $\begin{array}{l}\text { Many not poor } \\
\text { members }\end{array}$ \\
\hline 3 & No. of meetings & Four meetings & Two meetings & Less than 2 meetings \\
\hline 4 & $\begin{array}{l}\text { Timings of } \\
\text { meetings }\end{array}$ & $\begin{array}{l}\text { Night and after } 6 \\
\text { pm. }\end{array}$ & Morning $7 \& 9$ & Other timings \\
\hline 5 & $\begin{array}{l}\text { Attendance of } \\
\text { members }\end{array}$ & More than $90 \%$ & $\begin{array}{l}\text { pm. } \\
70 \text { to } 90 \%\end{array}$ & Less than $70 \%$ \\
\hline 6 & $\begin{array}{l}\text { Participation of } \\
\text { members }\end{array}$ & Very high level & Medium level & Low level \\
\hline 7 & $\begin{array}{l}\text { Savings collection } \\
\text { within group }\end{array}$ & Four times a month & Three times a month & \\
\hline 8 & Amount to be saved & Fixed amount & Varying & ------- \\
\hline 9 & $\begin{array}{l}\text { Interest on internal } \\
\text { loan }\end{array}$ & $\begin{array}{l}\text { Depends on the } \\
\text { purpose }\end{array}$ & $24 \%$ to $36 \%$ & More than $36 \%$ \\
\hline 10 & $\begin{array}{l}\text { Utilisation of } \\
\text { savings amount by } \\
\text { SHG }\end{array}$ & $\begin{array}{l}\text { Fully used by } \\
\text { members }\end{array}$ & Partly used by members & Poor utilisation \\
\hline 11 & Loan recoveries & More than $90 \%$ & 70 to $90 \%$ & \\
\hline 12 & $\begin{array}{l}\text { Maintenance of } \\
\text { books }\end{array}$ & $\begin{array}{l}\text { All are regularly } \\
\text { maintained and } \\
\text { updated }\end{array}$ & $\begin{array}{l}\text { Most important registers } \\
\text { (minutes, savings, loans etc) } \\
\text { are maintained \& updated }\end{array}$ & $\begin{array}{l}\text { Irregular in } \\
\text { maintenance and } \\
\text { update. }\end{array}$ \\
\hline 13 & $\begin{array}{l}\text { Accumulated } \\
\text { savings }\end{array}$ & More than Rs. 5000 & Rs. $3000-5000$ & Less than 3000 . \\
\hline 14 & $\begin{array}{l}\text { Knowledge of rules } \\
\text { of SHG }\end{array}$ & Known to all & ------------- & Not known to all \\
\hline 15 & Education level & $\begin{array}{l}\text { More than } 20 \% \\
\text { members can read } \\
\& \text { write }\end{array}$ & ----------- & $\begin{array}{l}\text { Less than } 20 \% \\
\text { members can read \& } \\
\text { write }\end{array}$ \\
\hline 16 & $\begin{array}{l}\text { Knowledge of } \\
\text { government } \\
\text { programmes }\end{array}$ & $\begin{array}{l}\text { All are aware of } \\
\text { govt. programs }\end{array}$ & Most of the members know & No one knows \\
\hline
\end{tabular}




\begin{tabular}{|l|}
\hline Source: NABARD \\
\hline Important: 1) SHGs with 12 to 16 "very good" factors can get factors loans immediately. \\
\hline 2) SHGs with 10 to 12 "very good" factors - need 10 to 12 "very good" factors 3 to 6 months' time to improve, before \\
loan is given \\
\hline 3) SHGs with rating of less than 10 "very good" factors will not be considered for loan. \\
\hline
\end{tabular}

- Delineate level or type of intended change targeted by communication strategy. It can be knowledge, behaviour or empowerment among others. Identify core components and elements of intervention. In this case, the training provided to SHG women whose aim to bring about behaviour change and empowerment is one of the key elements of intervention.

General training to women SHG members is given that includes maintaining record of meetings, amount collected from each member and total group savings. Although no formal training is given but they do get an update on growing vegetables in the backyard, opening a grocery shop at home and preparing 'sabzi masala'. Specialized training includes activities like 'pappad' making (a kind of snack) and 'chikankari'(embroidery) work. This can vary from 15 days to one month or 2 to 4 months. At times experienced women are asked to help new ones. Raw materials and marketing of products is carried through personal contacts and exhibitions. Specialized training is provided by local banks like Bank of India, and local government bodies which is free of cost and its duration is one month. For general training, women are given guidance about how to form SHG, role of office bearers, their functions, planning, training of group leaders and book keepers.

Specialized training is provided to improve activities like farming, livestock, handicraft and opening microenterprises. General training includes record keeping and minute writing whereas specialized training is provided by NABARD through MEDP (Micro Enterprise Development Programme) which is on location skill development training programme and LEDPs (Livelihood and Enterprise Development Programme). This is a customized programme for skill development and follow up training with due recognition and reward for SHG members and facilitators. General training is important to all members of SHG which includes maintaining record books like minutes book, members pass book, cash book, receipts and payments book. Specialized training is imparted by NGO activists and resource persons. Women are trained for maintaining records in registers and minutes of meeting. Special training is provided for vocational, risk taking activities where financial pros and cons are explained in simple terms. Ideas for community welfare activities are also discussed.

- $\quad$ Select communication model (s) and approaches.

The SHGs in the study used dialogue, action and reflection concepts embedded in Paulo Freire's philosophy of community mobilization. Before SHGs are formed, facilitators hold a meeting consisting of community leaders and elders of the village. The plan to form SHG is explained to them in detail. This is called community participation and is the right time to tell everyone that the meetings are not for "giving" anything. It is an opportunity for the poor families to come together and help each other. After meeting the elders and community leaders, the facilitators prepare for a 'start up meeting.' Usually they get one member from each of the identified families to come for a meeting. The process of forming groups normally takes five to six months.

- Select appropriate channels and media. This decision is taken reviewing all information collected during research phase.

One of the channels to navigate the functioning of SHG is selecting a leader who takes initiative and responsibility 
for the group. One of the efficient ways is to ask the following questions from the group.

- -Who should decide everything for SHG?

- Who benefits from SHG?

- Who should do the work?

- -How can work be shared?

The answer to these questions is that all members should decide everything and share work. The work can be shared by agreeing on one person to take up the work by rotation.

- Package content themes or design messages, keeping in mind audience needs and ways of thinking. The design of the message, no matter how creative, should be derived from local stakeholders worldview, not from that of the specialist.

\section{This Aspect is Covered in Communication Strategies Planned by SHG Members in Step 1 \& Step 2}

- Sustainable change (action plan implementation) which can be proved by showcasing the behavioural changes in women after joining SHGs.

Behavioural changes in terms of nature include developing leadership qualities, confidence, interpersonal skills and self-esteem. SHG members became familiar with banking procedures and record keeping. Members become vocal, confident, positive and can bargain and negotiate on the basis of their unity. Women on top positions in SHG like treasurer, President have leadership qualities, time management and good communication skills. Also, in terms of nature, women belonging to SHG are outgoing and positively respond to things shared by facilitators. In terms of activities, they are excited to meet peers for meetings in best clothes. After joining SHGs, the women have become enthusiastic, eager to learn, confident, like, they do not need any spokesperson for interactions. They are ready to market the products themselves, example, during "KumbhMela", they marketed jute bags, incense sticks themselves. After joining SHG, women have gained new knowledge of the outside world like visiting institutions for work and meeting new people. They have explored new income generating options and thus become confident with a sense of ownership. They feel less excluded and powerless from the societal setup. They also influence decision making in the household. Joining SHG has led to change in activities for women. Now they have shared responsibility among members. There is a clear cut division of work. Also, SHGs encourage the habit of savings which has led to development of micro-enterprises. After joining SHGs women witnessed increased social respect and status for themselves. Also, there is less abuse by male members. They felt independent, confident and could approach the authorities easily. They carved a new identity for themselves. They participated in decision making at households, attended group meetings, maintained records and talked confidently about saving money and helping each other. Along with household duties, they also did record keeping, reviewing, conducting meetings and discussions for SHG. They are more independent, less hesitant in talking to outsiders and carved a new identity for themselves.

The final objective of the study is discuss how participatory communication intervention outcomes have led to women empowerment. For this we need to understand profile of respondents first.

\section{Profile of the Respondents}

Frequency distribution containing data about age group, education, marital status, family type, number of family members, 
occupation of the respondent, occupation of the husband and land holdings were calculated for all the respondents.

Table 2: Demographic Profile of SHG Respondents $(\mathrm{N}=\mathbf{2 4 0})$

\begin{tabular}{|c|c|c|c|c|}
\hline Variables & & Classification & Frequency & $\%$ \\
\hline Age (in years) & $\begin{array}{l}\text { a) } \\
\text { b) } \\
\text { c) }\end{array}$ & $\begin{array}{l}\text { 20-35 Young } \\
\text { 36-50 Middle } \\
\text { 51-75 Old }\end{array}$ & $\begin{array}{c}167 \\
63 \\
10\end{array}$ & $\begin{array}{l}69.58 \% \\
26.25 \% \\
4.16 \% \\
\end{array}$ \\
\hline Education & $\begin{array}{l}\text { a) } \\
\text { b) } \\
\text { c) } \\
\text { d } \\
\text { e) } \\
\text { f) } \\
\text { g } \\
\text { h }\end{array}$ & $\begin{array}{l}\text { Illiterate } \\
\text { Functionally literate } \\
\text { Primary school } \\
\text { Secondary } \\
\text { High School } \\
\text { PUC } \\
\text { Graduate and above } \\
\text { Post-graduate \& above }\end{array}$ & $\begin{array}{c}92 \\
93 \\
41 \\
14 \\
0 \\
0\end{array}$ & $\begin{array}{c}38.33 \% \\
38.75 \% \\
17.08 \% \\
5.83 \% \\
0 \\
0\end{array}$ \\
\hline Marital Status & $\begin{array}{l}\text { a) } \\
\text { b) } \\
\text { c) }\end{array}$ & $\begin{array}{l}\text { Married } \\
\text { Unmarried } \\
\text { Widow }\end{array}$ & $\begin{array}{l}213 \\
15 \\
12\end{array}$ & $\begin{array}{c}88.75 \% \\
6.25 \% \\
5 \%\end{array}$ \\
\hline No. of family members & $\begin{array}{l}\text { a) } \\
\text { b) } \\
\text { c) }\end{array}$ & $\begin{array}{l}\text { Small (1-3 members) } \\
\text { Medium (4-6 members) } \\
\text { Large (7-9 members) }\end{array}$ & $\begin{array}{l}65 \\
95 \\
80\end{array}$ & $\begin{array}{l}27.08 \% \\
39.58 \% \\
33.33 \% \\
\end{array}$ \\
\hline Family Type & $\begin{array}{l}\text { a) } \\
\text { b) }\end{array}$ & $\begin{array}{l}\text { Nuclear } \\
\text { Joint }\end{array}$ & $\begin{array}{c}58 \\
182 \\
\end{array}$ & $\begin{array}{l}24.16 \% \\
75.83 \% \\
\end{array}$ \\
\hline Occupation of Husband & $\begin{array}{l}\mathrm{a} \\
\mathrm{b} \\
\mathrm{c}\end{array}$ & $\begin{array}{l}\text { Agriculture } \\
\text { Non-agriculture } \\
\text { Labourer }\end{array}$ & $\begin{array}{c}85 \\
111 \\
44 \\
\end{array}$ & $\begin{array}{l}35.41 \% \\
46.25 \% \\
18.33 \%\end{array}$ \\
\hline Occupation of Respondent & $\begin{array}{l}\mathrm{a} \\
\mathrm{b} \\
\mathrm{c}\end{array}$ & $\begin{array}{l}\text { Household cum agriculture } \\
\text { Business } \\
\text { Labour }\end{array}$ & $\begin{array}{c}75 \\
123 \\
42 \\
\end{array}$ & $\begin{array}{l}31.25 \% \\
51.25 \% \\
17.5 \% \\
\end{array}$ \\
\hline Land Holdings & $\begin{array}{l}\mathrm{a} \\
\mathrm{b} \\
\mathrm{c} \\
\mathrm{d}\end{array}$ & $\begin{array}{l}\text { Small } \\
\text { Marginal } \\
\text { Big } \\
\text { No Land } \\
\end{array}$ & $\begin{array}{l}75 \\
85 \\
38 \\
42 \\
\end{array}$ & $\begin{array}{l}31.25 \% \\
35.41 \% \\
15.83 \% \\
17.5 \% \\
\end{array}$ \\
\hline Income & $\begin{array}{l}\mathrm{a} \\
\mathrm{b} \\
\mathrm{c}\end{array}$ & $\begin{array}{l}\text { Low } \\
\text { Medium } \\
\text { High }\end{array}$ & $\begin{array}{l}117 \\
100 \\
23\end{array}$ & $\begin{array}{l}48.75 \% \\
41.66 \% \\
9.58 \%\end{array}$ \\
\hline
\end{tabular}

\section{Women Empowerment with Respect to Demographic Variables}

This section seeks to explore the influence of demographic variables like age, education level, marital status, family type, number of family members, occupation of the respondent, occupation of the husband, land holdings and income on different dimensions of women empowerment. Using Kruskal Wallis test procedures differences based on demographic profile and hypotheses were tested.

\section{Women Empowerment with Respect to Education}

Education may have a major influence on women belonging to SHGs with respect to several dimensions of women empowerment mentioned in the study.

On the basis of Kruskal-Wallis test result, the analysis indicates that when the groups are based on level of education, capacity building, behaviour change, level of empowerment, social, political, psychological and total empowerment are significantly differing among groups. 
Table 3: Women Empowerment with Respect to Education

\begin{tabular}{|c|c|c|c|}
\hline & Education & $\mathbf{N}$ & Mean Rank \\
\hline \multirow{6}{*}{ Capacity building } & \begin{tabular}{|l|}
1 \\
\end{tabular} & 93 & 135.01 \\
\hline & 2 & 91 & 122.76 \\
\hline & 3 & 41 & 97.93 \\
\hline & 4 & 14 & 78.50 \\
\hline & 5 & 1 & 78.50 \\
\hline & Total & 240 & \\
\hline \multirow{6}{*}{ Behaviour Change } & 1 & 93 & 138.84 \\
\hline & 2 & 91 & 118.49 \\
\hline & 3 & 41 & 95.24 \\
\hline & 4 & 14 & 88.00 \\
\hline & 5 & 1 & 88.00 \\
\hline & Total & 240 & \\
\hline \multirow{6}{*}{ Coalition Building } & 1 & 93 & 120.21 \\
\hline & 2 & 91 & 120.18 \\
\hline & 3 & 41 & 121.50 \\
\hline & 4 & 14 & 121.50 \\
\hline & 5 & 1 & 121.50 \\
\hline & Total & 240 & \\
\hline \multirow{6}{*}{ Resource Development } & 1 & 93 & 119.24 \\
\hline & 2 & 91 & 129.46 \\
\hline & 3 & 41 & 114.45 \\
\hline & 4 & 14 & 88.64 \\
\hline & 5 & 1 & 116.50 \\
\hline & Total & 240 & \\
\hline \multirow{6}{*}{ Level of Empowerment } & 1 & 93 & 107.63 \\
\hline & 2 & 91 & 112.91 \\
\hline & 3 & 41 & 140.71 \\
\hline & 4 & 14 & 192.57 \\
\hline & 5 & 1 & 170.50 \\
\hline & Total & 240 & \\
\hline \multirow{3}{*}{ Social Empowerment } & 1 & 93 & 126.86 \\
\hline & 2 & 91 & 126.26 \\
\hline & 3 & 41 & 106.10 \\
\hline
\end{tabular}

Table 4: Ranks

\begin{tabular}{|l|c|c|c|}
\hline & Education & $\mathbf{N}$ & Mean Rank \\
\hline \multirow{3}{*}{ Social Empowerment } & 4 & 14 & 85.50 \\
\cline { 2 - 4 } & 5 & 1 & 85.50 \\
\cline { 2 - 4 } & Total & $\mathbf{2 4 0}$ & \\
\hline \multirow{4}{*}{ Political Empowerment } & 1 & 93 & 124.82 \\
\cline { 2 - 4 } & 2 & 91 & 125.29 \\
\cline { 2 - 4 } & 3 & 41 & 112.87 \\
\cline { 2 - 4 } & 4 & 14 & 85.50 \\
\cline { 2 - 4 } & 5 & 1 & 85.50 \\
\cline { 2 - 4 } & Total & $\mathbf{2 4 0}$ & \\
\hline \multirow{4}{*}{ Legal Empowerment } & 1 & 93 & 118.06 \\
\cline { 2 - 4 } & 2 & 91 & 122.27 \\
\cline { 2 - 4 } & 3 & 41 & 124.84 \\
\cline { 2 - 4 } & 4 & 14 & 113.00 \\
\cline { 2 - 4 } & 5 & 1 & 113.00 \\
\cline { 2 - 4 } & Total & $\mathbf{2 4 0}$ & \\
\hline \multirow{3}{*}{ Psychological Empowerment } & 1 & 93 & 137.99 \\
\cline { 2 - 4 } & 2 & 91 & 123.24 \\
\hline
\end{tabular}




\begin{tabular}{|l|c|c|c|}
\hline \multirow{5}{*}{} & 3 & 41 & 98.05 \\
\cline { 2 - 4 } & 4 & 14 & 57.18 \\
\cline { 2 - 4 } & 5 & 1 & 51.00 \\
\cline { 2 - 4 } & Total & $\mathbf{2 4 0}$ & \\
\hline \multirow{5}{*}{ Cultural Empowerment } & 1 & 93 & 128.16 \\
\cline { 2 - 4 } & 2 & 91 & 120.52 \\
\cline { 2 - 4 } & 3 & 41 & 114.43 \\
\cline { 2 - 4 } & 4 & 14 & 89.50 \\
\cline { 2 - 4 } & 5 & 1 & 89.50 \\
\cline { 2 - 4 } & Total & $\mathbf{2 4 0}$ & \\
\hline \multirow{5}{*}{ Total Empowerment } & 1 & 93 & 139.30 \\
\cline { 2 - 4 } & 2 & 91 & 120.49 \\
\cline { 2 - 4 } & 3 & 41 & 96.43 \\
\cline { 2 - 4 } & 4 & 14 & 69.36 \\
\cline { 2 - 4 } & $\mathbf{5}$ & 1 & 76.50 \\
\cline { 2 - 4 } & Total & $\mathbf{2 4 0}$ & \\
\hline
\end{tabular}

Table 5

\begin{tabular}{|l|c|c|c|}
\hline & Chi-Square & Df & Asymp. Sig. \\
\hline Capacity building & 19.355 & 4 & 0.001 \\
\hline Behaviour Change & 15.494 & 4 & 0.004 \\
\hline Coalition Building & 0.612 & 4 & 0.962 \\
\hline Resource Development & 4.875 & 4 & 0.3 \\
\hline Level of Empowerment & 24.105 & 4 & 0 \\
\hline Social Empowerment & 10.879 & 4 & 0.028 \\
\hline Political Empowerment & 7.968 & 4 & 0.093 \\
\hline Legal Empowerment & 2.896 & 4 & 0.575 \\
\hline Psychological Empowerment & 25.626 & 4 & 0 \\
\hline Cultural Empowerment & 7.504 & 4 & 0.112 \\
\hline \multicolumn{1}{|c|}{ Total Empowerment } & $\mathbf{1 9 . 7 7 7}$ & $\mathbf{4}$ & $\mathbf{0 . 0 0 1}$ \\
\hline
\end{tabular}

The level of education influences capacity building $[\chi 2(d f=4, n=240)=19.355, p=.001<0.05]$. The more illiterate the individual is, more capacity will be built as their mean rank is highest (mean rank=135.01).

The level of education influences behaviour change $[\chi 2(\mathrm{df}=4, \mathrm{n}=240)=15.494, \mathrm{p}=.004<0.05]$. This means, the more illiterate women are participating in SHG, more the behaviour change (mean rank=138.84).

Similarly, the level of education influences level of empowerment $[\chi 2(\mathrm{df}=4, \mathrm{n}=240)=24.105, \mathrm{p}=.000<0.05]$. Women who have done their secondary level education are more empowered in comparison to other groups (mean rank=192.57).

Education also has an impact on social empowerment of women $[\chi 2(\mathrm{df}=4, \mathrm{n}=240)=10.879, \mathrm{p}=.028<0.05]$. Women who are illiterate are more socially empowered in comparison to the other groups (mean rank=126.86).

In a similar way, level of education plays a major role in political empowerment $[\chi 2(\mathrm{df}=4, \mathrm{n}=240)=7.968, \mathrm{p}$ $=.093<0.05]$. Women who are functionally literate are more politically empowered (mean rank=125.29).

The level of education also influences psychological empowerment $[\chi 2(\mathrm{df}=4, \mathrm{n}=240)=25.626, \mathrm{p}=.000<0.05]$. Women who are illiterate (mean rank=137.99) are more psychologically empowered in comparison to other groups.

The above analysis indicates that level of education has an impact on women empowerment.

\section{Women Empowerment with Respect to Marital Status}


The data indicates that when groups are based on marital status (Rank 1=married, 2=unmarried, 3=widow) capacity building, coalition building, level of empowerment, psychological empowerment and cultural empowerment are significantly differing among groups.

- There is more capacity building, coalition building and partnership among married women.

- Level of empowerment is more among unmarried women.

- Psychological and cultural empowerment is more among married women.

\section{Women Empowerment with Respect to Number of Family Members}

The number of family members may have a major influence on women belonging to SHGs with respect to several dimensions of women empowerment mentioned in the study.

On the basis of Kruskal-Wallis test result, the analysis indicates that when groups are based on number of family members (Rank 1=small, 2=medium, 3=large), capacity building, psychological empowerment, legal empowerment are significantly differing among groups.

- $\quad$ The smaller the family is, the more capacity building traits in SHG members.

- The data indicates that smaller the family is, more psychological empowerment among SHG members.

- Legal empowerment is more among families of medium size.

\section{Women Empowerment with Respect to Family Type}

The number of family members may have a major influence on women belonging to SHGs with respect to several dimensions of women empowerment mentioned in the study.

- Bigger the family size, more the capacity building potential among women. Resource development is more among respondents with bigger families.

- Level of empowerment and legal empowerment is more among respondents with smaller families.

\section{Women Empowerment with Respect to Occupation of the Husband}

Occupation of husband may have a major influence on women belonging to SHGs with respect to several dimensions of women empowerment mentioned in the study.

- There is more capacity building among women whose husbands are involved in non-agricultural tasks.

- There is more coalition building among women whose husbands are involved in both agriculture and nonagricultural occupations.

- $\quad$ Level of empowerment is highest among women whose husbands are doing labour work.

- Political and psychological empowerment is most among women whose husbands are doing agricultural work.

- Cultural empowerment is highest among women whose husbands are involved in non-agricultural tasks.

\section{Women Empowerment with Respect to Occupation of the Respondent}


Occupation of the respondent may have a major influence on women belonging to SHGs with respect to several dimensions of women empowerment mentioned in the study.

- Resource development is highest among respondents who work as labourers.

- Level of empowerment is highest among women who work at home as well as do agriculture work.

\section{Women Empowerment with Respect to Land Holdings}

Land Holdings may have a major influence on women belonging to SHGs with respect to several dimensions of women empowerment mentioned in the study.

- Land holding has an impact on capacity building. It is highest among women who have small land holdings.

- Behaviour change, resource development, political, legal, psychological and cultural empowerment is highest among women with no land.

- Level of empowerment is highest among women with big landholdings.

- Social empowerment is highest among with small land holdings.

\section{Women Empowerment with Respect to Income}

Income may have a major influence on women belonging to SHGs with respect to several dimensions of women empowerment mentioned in the study.

- Income has an impact on capacity building, behaviour change, social, political, psychological and cultural empowerment. It is highest among women with low income.

- Level of empowerment is highest among women in higher income group.

All the 8 null hypotheses had been tested for significance and the results of the hypotheses testing revealed that 5 out of 8 main hypothesis of the study are not supported. This shows that women empowerment varies significantly with respect to all chosen demographic variables except number of family members, family type and occupation of the respondent.

\section{CONCLUSIONS}

The foremost aim of the study was to understand the process of developing participatory communication interventions in the context of SHGs. The study indicates that the SHGs in the sample followed the steps outlined by World Bank to develop effective communication interventions.

The final objective is to gain insights into communication intervention outcomes (in this case behavior change of women involved) in context of SHGs. The joint World Bank and DFID publication (2006:17) states that hard facts cannot truly capture the complexity of human and social processes. The development context is dynamic and unpredictable, with unanticipated events and variables that are difficult to quantify. Human behavior change may not always follow a logical progression from knowledge to a change of attitude and finally behavior change. The qualitative and quantitative tools used highlight that there have been changes in day to day activities of women, in their attitude leading to social, political, economic, cultural, psychological and legal empowerment after they have become a part of SHGs.

\section{REFERENCES}


1. Belcher, Brian \& Palenberg, Markus. (2018). Outcomes \& Impacts of Development Interventions: Toward Conceptual Clarity. American Journal of Evaluation,39 (4). 478-495. https://doi.org/10.1177/1098214018765698

2. Denzin, Norman (1984). The Research Act. Englewood Cliffs, NJ: Prentice Hall. pp. 205-275.

3. Erlandson, David A., Edward Harris, Barbara L Skipper and Steve D Allen (1993), Doing Naturalistic Inquiry; A Guide to Methods. Newburry Park, CA: Sage.

4. Melkote, S.R., \& Steeves, H. L. (2001). Communication for development in the third word: Theory and practice for empowerment (2nd Ed). New Delhi: Sage.

5. Poland, B. D. (2002). Transcription Quality.Handbook of Interview Research: Context and Method, J. P. Gubrium and J. A. Holstein, eds. Thousand Oaks. CA: Sage. pp. 629-49.

6. Rice, Pranee Liamputtong and Douglas Ezzy (1999).Qualitative Research Methods: A Health Focus. Melbourne: Oxford University Press.

7. Servaes, J. (1996). Participatory communication: Research from a Freirean Perspective. 73-91. Retrieved from https://pdfs.semanticscholar.org/005f/d6b943f6e401f4c19d1ald518e803ee55a91.pdf

8. Servaes, Jan.(2008). Communication for Development and Social Change. Retrieved from https://www.researchgate.net/publication/272482459 Communication for Development and Social Change

9. Sharma, Sangeeta, and AK Bhattacharyya."Regional Rural Banks, Microfinance and Women Empowerment."International Journal of Agricultural Science and Research (IJASR) 7. 4, Aug 2017, 251-256

10. Soydan, Haluk.(2010).Intervention Research in Social Work. Research in Social Work Practice, 20(5), 457-458.

11. Tellis, Winston (1997). Application of a Case Study Methodology, The Qualitative Report, 3(3), 1-19.

12. Vasantha, S. "Challenges of self help group members towards income generation activity." International Journal of Accounting and Financial Management Research 4.2 (2014): 1-8.

13. Teshome, E., Zenebe, M., Metaferia,H. et al (2014). Participation and Significance of Self-help groups for Social Development: Exploring the Community Capacity in Ethiopia. Springer Plus 3,189. https://doi.org/10.1186/2193-1801-3-189.

14. Tufte, Thomas; Mefalopulos, Paolo. (2009). Participatory communication: A practical guide (English). World Bank working paper; no.170. Washington, DC: World Bank. http://documents.worldbank.org/curated/en/682081468166154717/Participatory-communication-a-practical-guide.

15. Tewari, Rajani. "Women's Empowerment through Walt Whitman and keki n. Daruwalla's Poems. "International Journal of English and Literature (IJEL) 9. 6, Dec 2019, 29-36

16. World Bank and DFID (Department for International Development). 2006. Listening and Learning: Measuring the Impact of Communication for Development. London: DFID

17. Mallikarjuna, K. G., and N. T. K. Naik. "Indicators of Women Economic Empowerment." International Journal of Humanities and Social Sciences (IJHSS) 3.3 (2014): 67-74.

\section{AUTHOR PROFILES}

Mili Sharma, With over 10 years of experience in academics, Ms Mili Sharma is pursuing her doctoral studies in the field of Development Communication. Her other areas of interest include advertising, mass communication theory and research. 
Dr Sanjay Mohan Johri, A multi-faceted journalist with over 35 years of experience in industry and academics, Prof (Dr) Sanjay Mohan Johri holds Ph. D. degree in Journalism. He has double Masters in Life Sciences and Journalism besides extensive experience of research in Political, social and Development Journalism. 